\title{
PEMAHAMAN PENDIDIK TENTANG MAKNA LAGU ANAK-ANAK SEBAGAI PEMBENTUK KARAKTER ANAK USIA DINI
}

\author{
Dwi Wahyu Riwanti, Hardika, Umi Dayati \\ Universitas Negeri Malang, Jalan Semarang 5 Malang 65145 \\ E-mail: dwi.wahyu0775@yahoo.com
}

\begin{abstract}
Educators understanding of the meaning of Song Children as the Character Shaping in Early Childhood. The focus of this research are: (1) to know children's understanding of educators about the song; (2) to know the meaning of the songs as a way of forming a character; and (3) to know the character which has been successfully established through songs. This research used qualitative approach with kind of case study research. Results of the research obtained were the forming of positive character depends on the actors affecting them. Learning messages delivered by the educators are through role-play technique based on the messages contained in the song's lyric.
\end{abstract}

Keywords: educators understanding, meaning of song children, character shaping in early childhood

\begin{abstract}
Abstrak: Pemahaman Pendidik Tentang Makna Lagu Anak-Anak Sebagai Pembentuk Karakter Anak Usia Dini. Fokus penelitian ini adalah: (1) untuk mengetahui pemahaman pendidik tentang lagu anak; (2) untuk mengetahui makna lagu sebagai pembentuk karakter; dan (3) untuk mengetahui karakter yang berhasil dibentuk melalui lagu. Metode penelitian yang digunakan yakni pendekatan kualitatif dengan jenis penelitian studi kasus. Hasil penelitian yang diperoleh bahwa pola pembiasaan perlu dilakukan berulang-ulang agar peserta didik bisa memiliki karakter yang positif. Pesan belajar yang disampaikan pendidik yakni melalui teknik bermain peran berdasarkan pesan yang terkandung dalam lirik lagu tersebut.
\end{abstract}

Kata kunci: pemahaman pendidik, makna lagu anak, pembentuk karakter anak usia dini

Anak usia dini merupakan anak usia emas yang biasa disebut dengan golden age. Belajarnya anak usia dini bisa dilakukan sambil bermain dan bermainnya anak usia dini bisa dilakukan dengan belajar. Musfiroh (2009) berpendapat belajar diartikan sebagai aktivitas produktif dan bermain diartikan sebagai aktivitas yang tidak produktif. Padahal, baik belajar maupun bermain merupakan aktivitas yang komplementer dan integralistik dalam kehidupan semua anak artinya melalui bermain itulah anak belajar. Aktivitas bermain yang mereka lakukan bagi anak usia dini merupakan pembelajaran yang secara tidak langsung sudah muncul tanpa mereka rencanakan, dan dengan bermain mereka akan dapat mengambil sisi pembelajaran bagi diri mereka sendiri yang tentu saja membutuhkan pengarahan dari seorang pendidik.
Lagu anak saat ini sudah banyak yang sudah dimodifikasi oleh pendidik Pendidikan Anak Usia Dini (PAUD), melalui modifikasi tersebut dapat mempermudah dalam menyampaikan pesan ataupun pembelajaran yang dilaksanakan. Bentuk aktivitas yang dimiliki oleh anak usia dini membutuhkan keceriaan bagi dirinya, untuk menciptakan keceriaan tersebut pendidik tentu sering melakukan modifikasi lagu dengan menggunakan bahasa dan kalimat yang sering didengar oleh anak usia dini. Belajarnya anak usia dini ialah melalui peniruan, dari adanya peniruan tersebut akan muncul suatu karakter-karakter pada diri anak usia dini. Pembentukan karakter yang baik dimulai sejak anak usia dini, karena pada usia dini itulah anak memiliki usia yang matang dan usia yang emas, ketika karakter sudah terbentuk sejak dini, maka ini bisa dijadikan sebuah modal bagi perkembangannya 
pada usia-usia selanjutnya. Fondasi yang matang perlu dilakukan sebagai langkah awal untuk membentuk karakter yang positif sesuai dengan tujuan yang diharapkan.

Setiap lembaga pendidikan anak usia dini tentu menerapkan lagu anak-anak dalam aktivitas pembelajaran yang dilakukan setiap hari. Penerapan lagu anak-anak tentu sudah berlangsung dalam setiap aktivitas yang ada di lembaga, akan tetapi penerapan makna yang terkandung dalam lagu tersebut belum bisa dimaksimalkan oleh pendidik bagi perkembangan peserta didiknya. Lagu yang diterapkan hanya bersifat sebagai suatu aktivitas rutin yang diterapkan di lembaga. Bahkan lagu anak saat ini sudah lepas dari kehidupan mereka. Saat ini, lagu anak adalah barang langka. Kalaupun ada, sebagian besar lagu-lagu tersebut sudah kehilangan 'ruh' dari unsur anaknya, walaupun lagu-lagu masih tetap ceria. Namun seperti ada yang hilang dari dalam lagu tersebut (Latif, 2013). Seperti yang terlihat saat ini anak usia dini seringkali menyanyikan lagu-lagu dewasa yang seharusnya tidak dikonsumsi untuk mereka. Pembiasaan yang mereka dapat dan mereka lihat akan dilakukan sesuai dengan yang ada di depannya.

Pembentukan pendidikan karakter untuk anak usia dini tidak hanya dilakukan melalui pembelajaran dan pendidikan yang bersifat formal saja, tetapi juga dapat dilakukan melalui kegiatan yang bersifat nonformal atau bisa dikatakan diluar kegiatan belajar. Salah satunya melalui cara belajarnya anak usia dini atau juga bisa dilakukan melalui bermainnya. Menurut Wibowo (2012) karakter merupakan istilah yang menunjuk kepada aplikasi nilai-nilai kebaikan dalam bentuk tindakan atau tingkah laku. Setiap tindakan yang dilakukan oleh seseorang itu merupakan cerminan dari karakter yang dimilikinya. Kemunculan karakter sesuai dengan apa yang dilakukan pada saat itu. Melalui penerapan lagu pada setiap lembaga sesuai dengan kepahaman yang dimiliki oleh pendidik akan membuat peserta didik lebih mudah dalam membentuk karakter positif.

Makna yang terkandung dalam setiap lirik lagu anak akan bisa menjadikan anak memahami dan juga dapat menerapkan pesan yang terkandung didalamnya, misalnya karakter mengenal arti keagamaan, arti kerjasama, arti kepedulian, arti dari kepatuhan, kesopanan, dan kedisiplinan. Aspek nilai karakter tersebut akan ada dalam setiap makna yang terkandung dalam setiap lagu. Menurut Hastomi dan Sumaryati (2012) lagu anak yang didalamnya kaya akan nilai-nilai budi pekerti bisa memberikan pengaruh baik dalam pertumbuhan mereka. Budi pekerti adalah watak atau tabiat khusus seseorang untuk berbuat sopan dan menghargai pihak lain yang tercermin dalam perilaku dan kehidupannya (Kurniawan, 2013). Berdasarkan pemaparan tersebut, fokus penelitian ialah: (1) untuk mengetahui pemahaman pendidik tentang lagu anak; (2) untuk mengetahui makna lagu sebagai pembentuk karakter; dan (3) untuk mengetahui karakter yang berhasil dibentuk melalui lagu.

\section{METODE}

Penelitian ini menggunakan pendekatan kualitatif dengan jenis penelitian studi kasus. Dalam penelitian kualitatif, data yang diambil adalah data sebagaimana adanya yang terdapat dalam situasi sosial yang meliputi pelaku, aktivitas dan tempat. Tempat atau lokasi penelitian ini adalah PAUD Sahabat Ananda Perum Puncak Permata Sengkaling Blok K-1 Malang. Kasus menarik yang ada dalam lembaga yakni adanya penerapan lagu-lagu yang digunakan sebagai penyampaian pesan positif kepada peserta didik. Melalui lagu peserta didik bisa lebih mudah dalam memahami maksud yang disampaikan oleh pendidik. Karena lagu sudah menjadi aktivitas rutin bagi anak usia dini. Dalam penelitian ini peneliti bertindak sebagai instrumen kunci yang bertugas untuk menggali dan mengolah informasi atau data. Kehadiran peneliti sangat penting kedudukannya, pada penelitian kualitatif peneliti memiliki kedudukan sebagai instrumen penelitian yang utama (Arikunto, 2010).

Infomasi diperoleh dari 6 pendidik yang berada di lembaga. Pengumpulan data dilakukan dengan menggunakan teknik wawancara, observasi dan studi dokumentasi. Wawancara dilakukan dengan menggali data sesuai dengan fokus, pada observasi peneliti bertindak secara partisipatif, dengan maksud penelitu langsung melakukan pengamatan secara langsung agar data yang diperoleh sesuai dengan fokus. Dokumentasi yang dilakukan sebagai bukti data-data yang telah didapat ketika melakukan penelitian. Data yang telah 
dikumpulkan kemudian dianalisis menggunakan model analisis Miles dan Huberman yang terdiri dari: (1) reduction; (2) display; dan (3) conclusion drawing and verifying (Ulfatin, 2013). Untuk menguji keabsahan penelitian, peneliti menggunakan teknik triangulasi sumber dan teknik. Menurut Iskandar (2009) penelitian yang menggunakan teknik triangulasi dalam pemeriksaan melalui sumbernya artinya membandingkan atau mengecek ulang derajat kepercayaan suatu informasi yang diperoleh melalui waktu dan alat yang berbeda. Triangulasi sumber dilakukan dengan dua informan yakni kepala sekolah dan pengendali mutu akademik lembaga. Dengan menggunakan dua informan sebagai pengecekan keabsahan data sudah cukup memperkuat argumen dan hasil yang sudah diperoleh dari keenam pendidik.

\section{HASIL}

\section{Lagu yang diterapkan di Lembaga}

Jumlah lagu yang diterapkan di lembaga berjumlah 17 lagu yang masing-masing terbagi dalam lagu sebelum kegiatan belajar, saat belajar dan sesudah belajar. Lagu-lagu yang diterapkan di lembaga merupakan lagu yang diperoleh baik dari seminar, modifikasi guru serta kumpulan dari HIMPAUDI Kecamatan Dau. Pertemuan HIMPAUDI dilaksanakan setiap satu bulan sekali untuk mengevaluasi kinerja dari pendidik. Setiap lagu memiliki pesan moral serta pesan belajar yang berbeda, penerapan lagu digunakan sebagai teguran pendidik kepada peserta didik yang melakukan kesalahan agar bisa memperbaiki kesalahan yang sudah dilakukan tersebut tanpa mengandung unsur paksaan yang dirasakan oleh peserta didik. Melalui lagu peserta didik dapat merasakan keceriaan yang dilakukan saat berada di lingkungan sekolah. Teguran yang diberikan langsung akan membuat peserta didik merasakan tekanan-tekanan.

\section{Pemahaman tentang Makna Lagu}

Pemahaman pendidik tentang makna lagu bisa dipahami dengan cara dicermati secara berulangulang yakni dengan menggunakan bahasa yang singkat dan mudah dipahami baik untuk anak usia dini maupun orang dewasa. Melalui pemahaman berulang-ulang pendidik bisa menggunakan kalimat yang semakin mudah dalam penyampaiannya.
Peserta didik dalam memahami makna yang ada dalam lagu berdasarkan kepahaman yang sudah dijelaskan oleh pendidik, dengan pendidik memberikan kepahaman yang singkat peserta didik bisa mengerti makna tersebut berdasarkan contoh yang diberikan oleh pendidik sesuai dengan makna pesan belajar yang akan disampaikan kepada peserta didik. Karena belajarnya anak usia dini ialah melalui peniruan dengan apa yang sudah dilihatnya, dengan hal ini maka pendidik tentu dapat memberikan contoh yang baik terhadap peserta didik agar bisa terbentuk karakter positif sesuai dengan yang diharapkan oleh pendidik.

\section{Pembentukan Karakter Peserta Didik}

Karakter peserta didik menunjukkan pada karakter positif, dapat mengenali kata santun. Dapat mengucap permisi ketika lewat di depan orang, dapat mengucapkan terimakasih serta meminta maaf ketika melakukan kesalahan. Dapat tanggung jawab pada aktivitas yang dilakukannya. Pembentukan karakter yang muncul dalam diri peserta didik yakni melalui masing-masing metode yang diterapkan oleh pendidik. Salah satunya yakni dengan menggunakan teknik breafing setiap pagi sebelum kegiatan belajar dimulai dan menggunakan teknik time out untuk peserta didik yang belum bisa menghargai dan menjaga sikap saat pembelajaran dimulai. Time out berlangsung pada saat aktivitas sudah dimulai, cara ini ialah dengan membawa peserta didik yang melakukan kesalahan atau belum bisa menjaga sikap ke dalam kelas bersama guru, kemudian di dalam kelas tersebut peserta didik melakukan istighfar bersama pendidi dengan tujuan peserta didik bisa merubah dan kembali bisa menjaga sikap baik kepada guru ataupun teman.

\section{PEMBAHASAN}

\section{Lagu yang diterapkan di Lembaga}

Penerapan lagu di lembaga banyak digunakan pada saat breafing atau pembukaan sebelum kegiatan dimulai, dengan breafing anak tidak akan merasa bosan dalam melakukan proses kegiatan belajar mengajar. Penerapan lagu yang banyak akan membuat anak bisa merasa nyaman dalam melaksanakan proses pembelajaran. Menurut Hastomi dan Sumaryati (2012) semakin banyak lagu yang dipilih, anak akan dapat mendapat alternatif 
untuk menikmatinya. Dengan begitu, anak tidak akan mudah bosan dengan pilihan yang itu-itu saja. Pendapat lain menurut Jannah (2013) yang menyatakan bahwa aplikasi pembelajaran musik dirasa sebagai langkah awal dalam menyiasati terbengkalainya dua unsur lainnya, yaitu belajar dan bermain.

Lagu yang dipilihkan memiliki sifat yang mudah untuk dipahami, untuk dihafalkan, dan mudah untuk diterapkan dalam kehidupan seharihari. Pemilihan kata agar dapat diulang-ulang dalam lirik juga perlu untuk bisa dilakukan. Mengutip dari Kompas (2015) menyebutkan lirik yang harusnya digunakan untuk anak usia dini yakni menggunakan kata-kata yang sederhana dan tidak terlalu panjang (terutama lagu yang mengandung nilai pendidikan dan moral), boleh panjang asalkan mengandung sebuah cerita yang menarik dan mudah dipahami anak-anak, dan memiliki kata-kata yang berbobot. Ortiz (2002) menyimpulkan bahwa koleksi lagu anak-anak yang dibuat sangat baik, dengan ritme yang menarik dan menghentak. Dengan pemilihan lagu tersebut mampu membuat anak merasa ceria dengan keadaan ketika di lingkungan sekolah.

\section{Pemahaman tentang Makna Lagu}

Pendidik PAUD sudah tidak asing dengan istilah bernyanyi dan musik. Salah satu metode yang tepat digunakan dalam pembelajaran anak usia dini adalah metode bernyanyi (Jannah, 2013). Sebagai pendidik tentu harus memahami makna yang ada dalam lagu agar makna dan pesan bisa tersampaikan dengan baik serta bisa diterima dan diterapkan oleh peserta didik. Ortiz (2002) berpendapat bahwa dari semua keterampilan yang harus dipelajari anak-anak sepanjang masa perkembangan mereka, yang paling penting adalah mendengarkan dan berkomunikasi. Pada masa inilah anak dapat mengetahui dunianya berdasarkan pendengaran serta cara komunikasi mereka.Rasa ingin tahu anak usia dini dapat terjadi melalui proses mendengarnya yang dapat menimbulkan pertanyaan. Sejalan dengan pendapat Yusuf (2010) yang menyatakan bahwa ingin tahu (curiosity) yaitu perasaan ingin mengenal, mengetahui segala sesuatu atau objek-objek, baik yang bersifat fisik maupun nonfisik. Perasaan ini ditandai dengan pertanyaanpertanyaan yang diajukan oleh anak.
Menjadi pendidik merupakan salah satu bentuk tugas yang harus dilaksanakan agar peserta didik bisa memiliki kemampuan yang baik sesuai dengan usaha yang dilakukan oleh masing-masing pendidik. Salah satu bentuk yang dilakukan pendidik di lembaga PAUD Sahabat Ananda ialah dengan memberikan pesan melalui lagu yang diterapkan. Salah satu persyaratan khusus yang harus dimiliki oleh guru PAUD yakni mampu bernyanyi, bercerita, dan bermain, termasuk harus mampu memainkan alat musik (Suyadi, 2011). Melalui lagu tersebut pendidik bisa menyampaikan pesan kepada peserta didik dengan mudah. Dasar inilah harus dipahami dan diterapkan dahulu oleh pendidik. Penggunaan lagu dapat dijadikan sebagai media bagi pendidik dalam menyampaikan pesan belajar kepada peserta didik.

Bentuk kreatif dari pendidik yakni dapat memberikan lagu-lagu yang dimodifikasi sesuai dengan yang sering didengar oleh peserta didik. Pemahaman pendidik berawal dari kepahaman pemilihan lagu yang diterapkan di lembaga, selanjutnya pendidik melakukan penafsiran syair untuk mengetahui makna. Saat makna sudah ada pemdidik merangkai kalimat menjadi bahasa yang mudah untuk dipahami peserta didik.

\section{Makna Lagu sebagai Pembentuk Karakter}

Musik dapat digunakan sebagai penanaman karakter yang kuat pada anak, karena musik memang merupakan hal yang sangat menarik dan menyenangkan bagi anak-anak. Tanpa sadar mereka sudah bisa diperkenalkan pendidikan karakter (Rosmiati, 2014). Dengan mengenalkan lagu-lagu anak diharapkan bukan saja hiburan dan kesenangan yang dapat dicapai oleh anak, akan tetapi juga dapat memahami makna dari lagu-lagu yang diterapkan tersebut. Pemahaman makna ini tentu membutuhkan arahan dan bimbingan dari orang-orang yang lebih dewasa yang berada di sekitar anak-anak, misalnya guru ketika berada di sekolah dan orangtua di rumah. Adanya kerjasama ini dapat membantu tercapainya tujuan yang ingin dilaksanakan baik dari keinginan orangtua maupun dari pendidik.

Makna lagu sebagai pembentuk karakter sesuai dengan aspek perkembangan yang akan dibentuk oleh pendidik. Lagu yang sudah diterapkan dalam lembaga merupakan lagu yang me- 
miliki makna pembentukan karakter dasar bagi anak usia dini. Setiap lagu yang diterapkan dalam lembaga memiliki makna yang berbeda-beda. Terdapat makna lagu sebagai usaha pendidik dalam memberikan motivasi kepada peserta didik, selain itu juga ada lagu yang mengandung makna untuk melatih kemandirian anak. Makna lain juga terdapat sebagai pengenalan nilai agama yang menjadikan aspek penilaian pada spiritul, makna ke sosial yakni dengan saling berbagi ataupun mengasihi.

Kurniawan (2013) berpendapat bahwa berlangsungnya pendidikan karakter diharapkan peserta didik mampu menguasai aspek seperti nilai religious, jujur, toleransi, disiplin, kerja keras, kreatif, mandiri, demokratis, rasa ingin tahu, semangat kebangsaan, cinta tanah air, menghargai prestasi, bersahabat, cinta damai, gemar membaca, peduli lingkungan, peduli sosial, dan tanggung jawab. Masing-masing aspek terdapat dalam pesan lagu yang disampaikan oleh pendidik. Aspek karakter tersebut akan ada dalam setiap lagu yang diterapkan dengan sesuai tema pada saat itu juga.

Ada beberapa kandungan yang terdapat dalam makna lagu anak yang dapat dikembangkan untuk anak usia dini, yakni pesan moral yang berguna bagi anak-anak (kebaikan, persahabatan, kerajinan), dan tidak mengandung hal-hal yang hanya diperuntukkan untuk orang-orang dewasa (cinta, selingkuh, pertengkaran). Mengandung nilai pendidikan (sarana mempermudah anak-anak untuk belajar tentang sebuah materi mata pelajaran tertentu (misalnya, lagu balonku: tentang warna).

\section{KESIMPULAN DAN SARAN}

\section{Kesimpulan}

Berdasarkan temuan penelitian dan pembahasan, hasil penelitian ini dapat disimpulkan bahwa pendidik memahami makna lagu dengan cara membaca berulang-ulang serta menerapkan dalam aktivitas sehari-hari dengan cara bermain peran. Melalui pemahaman pendidik pesan belajar yang ada dalam lagu akan lebih mudah disampaikan kepada peserta didik. Makna lagu yang dijadikan sebagai pembentuk karakter yakni lebih kepada pesan moral yang harus diterapkan oleh peserta didik saat berada di rumah. Pendidik dalam menyampaikan pesan berulang-ulang agar peserta didik bisa lebih memahami. Dengan pengulangan tersebut peserta didik bisa mudah untuk mengingat pesan yang disampaikan oleh pendidik. Peserta didik mengenal kata-kata adab yang baik. Seperti dengan membiasakan minta maaf apabila melakukan kesalahan, mengucap terimakasih ketika sedang diberi oleh teman, mengucap permisi ketika lewat didepan orang. Selain itu juga terdapat karakter peserta didik mampu menjaga sikap serta tanggung jawab kepada diri sendiri.

\section{Saran}

Berdasarkan kesimpulan diatas, maka saran yang diajukan adalah guru agar menerapkan lagulagu yang dimodifikasi lebih banyak lagi. Guru menggunakan lagu sesuai dengan aspek karakter yang ingin dibentuk dalam sebuah jadwal untuk masing-masing peserta didik. Guru harus kenali karakter dari masing-masing peserta didik agar lebih mudah dalam membentuk karakter melalui lagu-lagu yang diterapkan. Guru harus memahami makna yang ada dalam lagu dengan menggunakan kalimat yang singkat untuk bisa disampaikan kepada peserta didik.

\section{DAFTAR RUJUKAN}

Arikunto, S. 2010. Prosedur Penelitian Suatu Pendekatan Praktik. Jakarta: Rineka Cipta.

Hastomi, I., \& Sumaryati, E. 2012. Terapi Musik. Jogjakarta: Javalitera.

Iskandar. 2009. Metodologi Penelitian Pendidikan dan Sosial (Kuantitatif dan Kualitatif). Jakarta: Prestasi Pustaka.

Jannah, L. A. 2013. Kesalahan-kesalahan Guru PAUD yang Sering Dianggap Sepele. Jogjakarta : DIVA Press.

Kompas. 2015. Lagu Anak Seluk Beluk Sejarah, (Online), (http://forum.kompas.com/ musik/34175-lagu-anak-seluk-beluk-sejarahdll.html), diakses 2 Mei 2016.

Kurniawan, S. 2013. Pendidikan Karakter Konsepsi dan Implementasinya secara Terpadu di Lingkungan Keluarga, Sekolah, Perguruan Tingi, dan Masyarakat. Yogyakarta: Ar-Ruzz Media.

Latif, M. 2013. Orientasi Baru Pendidikan Anak Usia Dini: Teori dan Aplikasi. Jakarta: Kencana. 
Musfiroh, T. 2009. Menumbuhkembangkan BacaTulis Anak Usia Dini. Jakarta: PT Grasindo.

Ortiz, J. M. 2002. Menumbuhkan Anak-anak yang Bahagia, Cerdas dan Percaya Diri dengan Musik. Jakarta: PT Gramedia Pustaka Utama.

Suyadi. 2011. Manajemen PAUD TPA-KB-TK/RA. Yogyakarta: Pustaka Belajar.

Ulfatin, N. 2013. Metode Penelitian Kualitatif di Bidang Pendidikan. Malang: Fakultas Ilmu Pendidikan.
Yusuf, S. 2010. Psikologi Perkembangan Anak dan Remaja. Bandung: PT Remaja Rosdakarya.

Wibowo, A. 2012. Pendidikan Karakter Usia Dini (Strategi Membangun Karakter di Usia Emas). Yogyakarta: Pustaka Pelajar.

Rosmiati, A. 2014. Teknik Stimulasi dalam Pendidikan Karakter Anak Usia Dini melalui Lirik Lagu Dolanan, (Online), (http://journal. isi.ac.id), diakses 6 Maret 2015. 